Volume 9. No. 3, March 2021

International Journal of Emerging Trends in Engineering Research

Available Online at http://www.warse.org/IJETER/static/pdf/file/ijeter03932021.pdf

https://doi.org/10.30534/ijeter/2021/03932021

\title{
Effect of Solid Waste Disposal on Ground Water Quality in Mgboji, NdokiOyigbo Local Government Area, Rivers State, Nigeria
}

\author{
Eni, D. Imoke', Oka, P. Onen², \\ ${ }^{1}$ Department of Environmental Resource Management, University of Calabar \\ ${ }^{2}$ Department of Geography and Environmental Science, University of Calabar
} devalsamimoke@unical.edu.ng

\section{ABSTRACT}

One of the spiteful impacts of landfill sites is the emission of leachates into ground water. The study examined the impact of landfill site on ground water in MgbojiNdokiOyigbo Local Government Area, Rivers State. The study sought to assess the quality of underground water in relation to WHO best standard. The study adopted a laboratory examination, assessing water quality parameters such as hardness, TDS, EC, DO, BOD, chlorine, zinc, $\mathrm{pH}$, temperature, salinity, COD and copper. The study sampled 15 boreholes that are up to or less than $500 \mathrm{~m}$ from the landfill site and another borehole at $1000 \mathrm{~m}$ from the landfill site, which serves as a control point for the study. The paired sample t-test was adopted in analyzing the formulated hypotheses. The result of the study revealed that bore holes that are $500 \mathrm{~m}$ or less are more contaminated than boreholes that are $1000 \mathrm{~m}$ away from the landfill sites. Furthermore, water quality from boreholes that are $500 \mathrm{~m}$ or less are unfit for human consumption because they do not meet the acceptable limit postulated by WHO, while boreholes that are $1000 \mathrm{~m}$ away from the landfill are suitable for human consumption because they meet the acceptable limit by WHO. The study recommends that government should regulate human settlement and development within areas that are too close to landfill sites.

Key words: Waste management; Landfill site; Water quality; WHO standard

\section{INTRODUCTION}

Solid waste management constitutes one of the most crucial environmental problems facing cities of the world, especially African cities (Anestina, Adetola, \&Odafe, 2014). The problems posed by improper and ineffective management of solid waste has become an issue of global concern over the past decades (Schwarz-Herion, Omran\& Rapp, 2008). The impact of poor waste management impacted different components including but not limited to soil, water and to air quality (Shegow\&Funwie, 2020). Furthermore, the magnitude of commercialization, industrialization and population expansion in many cities of the world has also aggravated the impact of waste management on the environment (Abur, Oguche\&Duvuna 2014). Landfill waste management involves the designation of land for waste disposal in such a manner that it does not pollute the surrounding environment especially, groundwater (Ezechi, Nwabuko, Enyinnaya\& Babington, 2017).
However, the adoption of landfill sites for waste management has become more threatening to human lives mostly as a result of contaminant that leaches from the landfill sites (Akor, Ayotamuno, Aman \&Enokela, 2013).One of the spiteful impacts of landfill sites is the emission of leachates into ground water. Leachate from landfills is usually highly concentrated with complex effluents which contain dissolved organic matter and inorganic matter (Hossain, 2014). Pollution due to heavy metals in ground water where it is used as drinking and the likely risk to population health has been studied extensively (Elumalai, Brindha, \& Lakshmanan 2017). Thousands of lives are lost every year to environmental related diseases from consumption of polluted water resources. It is noted that the consumption of ground water resources located around these landfill sites are known to cause issues such as typhoid, dysentery, guinea worm disease, cholera, dengua, diarrhea, hepatitis and a host other water related disease (Solidarities 40, 2012).

The influence of landfill leachate on the ground water has given intense attention in many studies in current years as a result of the increasing emergency of underground water pollution from landfill sites (Nagarajan, Thirumalaisamy\&Lakshumanan, 2012), a problem similarly observed inNdoki, Oyigbo LGA, River State, Nigeria. Hence, this study is designed to examine the impact of landfill site on ground water in MgbojiNdokiOyigbo LGA, Rivers State.

\section{STUDY AREA}

Oyigbo is a local government in River State and lies within the coordinates $4.8781^{\circ} \mathrm{N}$ and $7.1283^{\circ} \mathrm{E}$. Oyigbo is bounded to the East by Abia State, to the South by Khana LGA, to the West by Eleme, Tai and ObioAkpo LGA and to the North by Etche LGA. The vegetation in Oyigbo is characterized by rainforest and it is equally rich in tropical biodiversity. The climate of Oyigbo LGA is a tropical climate. Rainfall is significant most months of the year, and the short dry season has little effect. The average annual temperature is $26.4{ }^{\circ} \mathrm{C} \mid 79.5^{\circ} \mathrm{F}$ in Port Harcourt. Precipitation here is about $2708 \mathrm{~mm}$ or 106.6 inch per year. The driest month is January, with $36 \mathrm{~mm} 1.4$ inch of rainfall. It has an elevation of just $139 \mathrm{~m}$ above sea level, the landscape of the region comprises the coastal palms by a maze of swamps, creek and water ways (Ekeke, 2015). Oyigbo is located within the lower delta plain reported to have been formed during the Holocene of the quatemary period by the accumulation of sedimentary deposits In addition, the major geological characteristics are sedimentary alluvium. Oyigbo lies 
Eni, D. Imoke et al., International Journal of Emerging Trends in Engineering Research, 9(3), March 2021, 169 - 175

about 15-31 meters above sea level. The soil types are generally shallow, young, poorly drained soils and acid sulphate soils.

Oyigbo has an estimated population of about 222,687 people according to 2006 population census. Access roads are numerous in Oyigbo. Oyigbo is an industrial centre as it has a large number of multinational firms as well as other industrial concerns, particularly business related to the petroleum industry. It is one of the chief oil producing community in Rivers State in Nigeria. Also, inhabitants engage in farming as a dominant economic activity in Oyigbo L.G.A. Yam, cassava, vegetable are largely grown. Other forms of economic activities include trading and fishing.

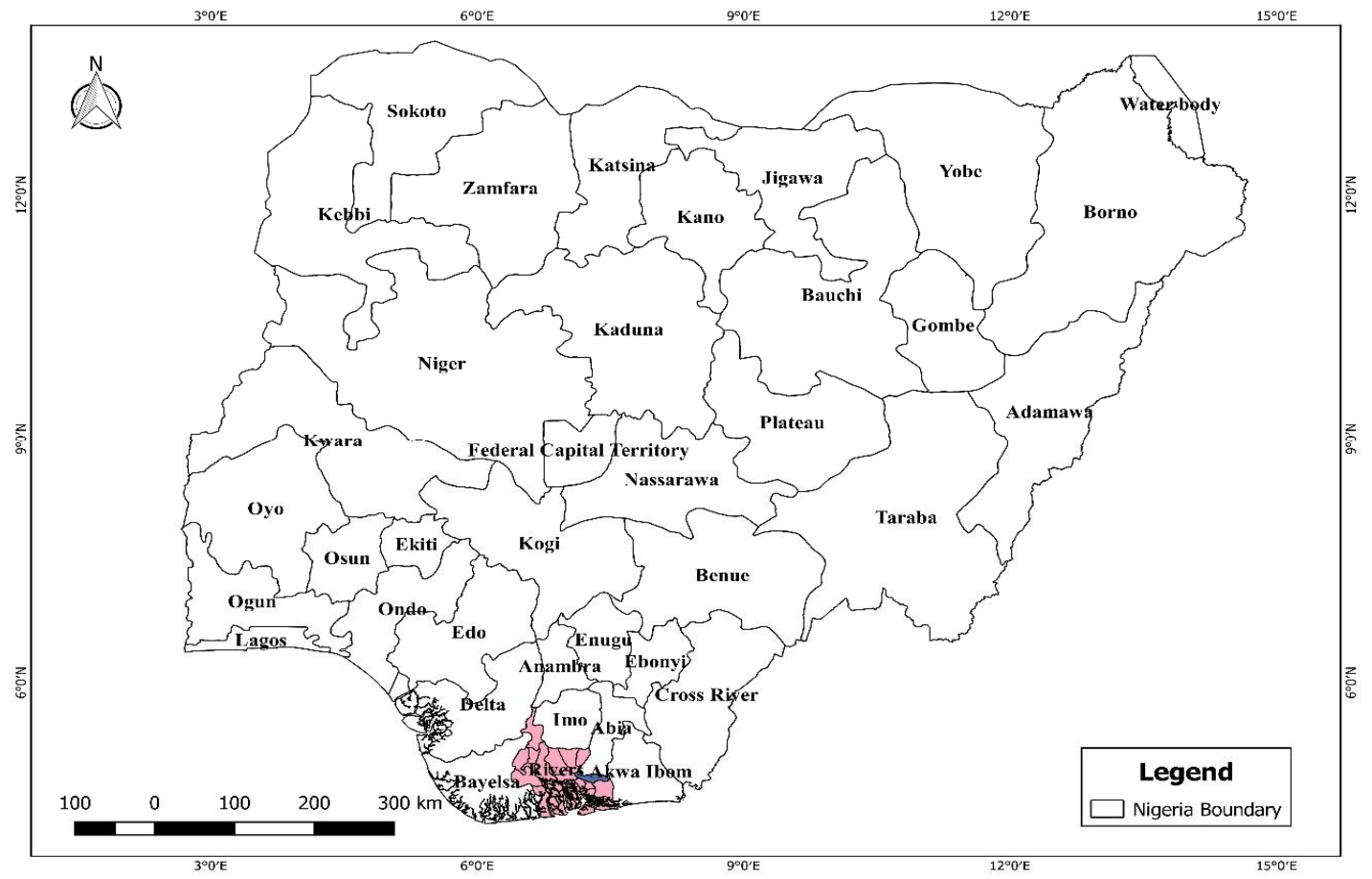

Figure 1: Map of Nigeria

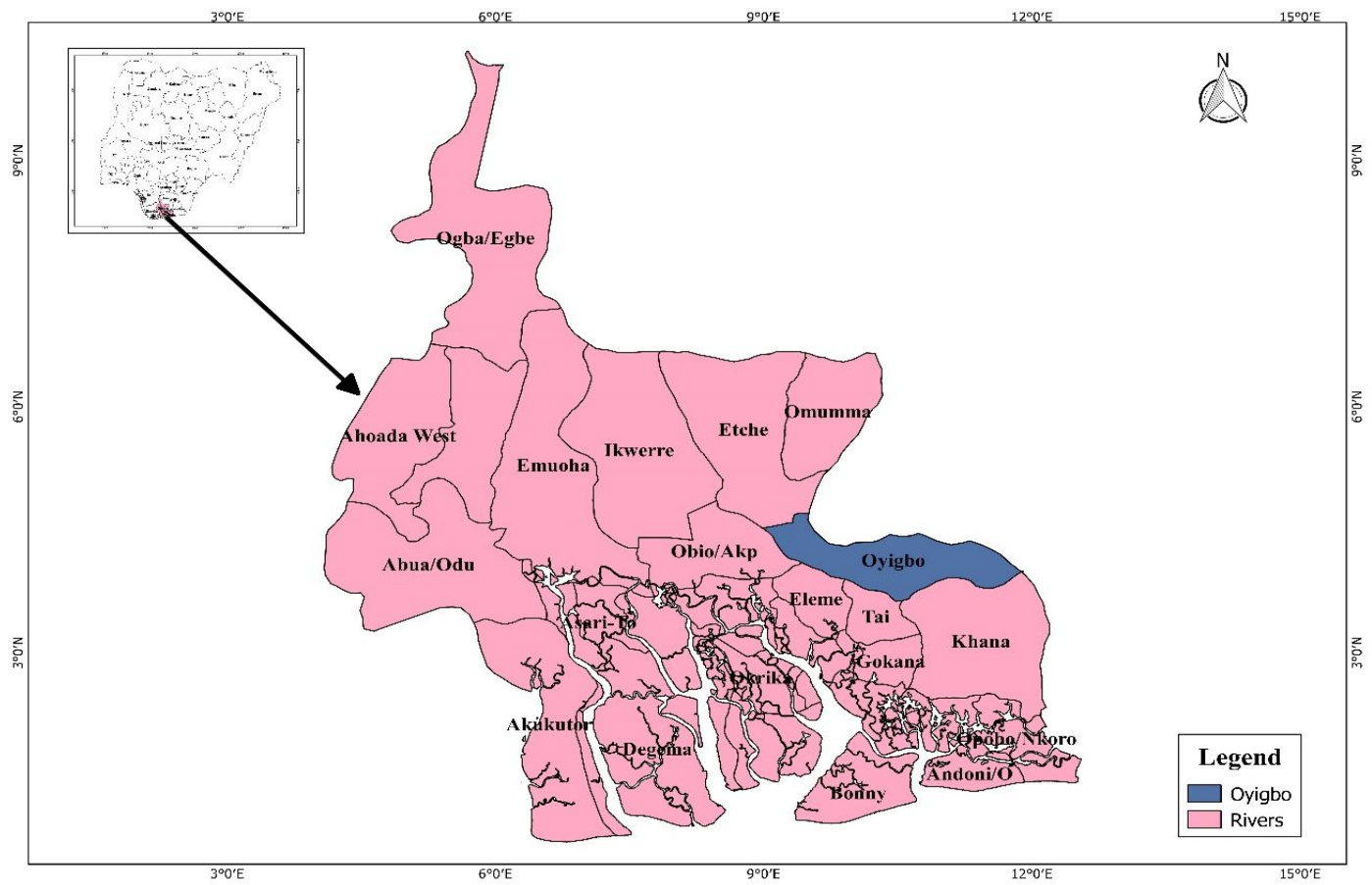

Figure 2: Map of River State showing Oyigbo LGA. 
Eni, D. Imoke et al., International Journal of Emerging Trends in Engineering Research, 9(3), March 2021, 169 - 175

\section{MATERIALS AND METHODS}

The study adopted a laboratory experimental research design using a continuous data type obtained from primary sources. Water samples were collected from taps around boreholes located within households around landfill sites. As a rule of thumb, fifteen sampled boreholes were chosen from locations within the landfill sites. Another sample point was selected away from the landfill site to serve as the control point. Due to the nature of the research, water samples were obtained from a controlled environment. A receptacle was used in collecting water samples from boreholes located within the landfill sites and borehole located outside the land fill site. The receptacle was cleaned with water from the borehole and used in collecting water samples, which were then labelled and stored in a cool container before taken to the laboratory for analysis. Descriptive, inferential statistics was adopted to analyze data in this study. Descriptive statistics include maps, charts, percentages and frequency tables. The paired sample t-test was conducted in testing both hypotheses.

The formula for the paired sample $t$ test is given as thus;

The student t-test formula is given as:

$$
t=\sqrt{\frac{\left(\sum D\right) / N}{\frac{\sum D^{2}-\left(\frac{\left(\sum D\right)^{2}}{N}\right)}{(N-1)(N)}}}
$$


Eni, D. Imoke et al., International Journal of Emerging Trends in Engineering Research, 9(3), March 2021, 169 - 175

\section{RESULT}

Table 1 revealed that some of the physico - chemical parameters at borehole locations 4,5,6,7,8,12 and 15 were above the recommended WHO standard. Also their mean and standard deviation values also exceeded the WHO standard for drinking water.

Table 1: Physico-Chemical Parameter of Water Quality

\begin{tabular}{|c|c|c|c|c|c|c|c|c|c|c|c|c|c|}
\hline $\begin{array}{l}\mathrm{BH} \\
\text { Number }\end{array}$ & ph & temp (oc) & $\begin{array}{l}\mathrm{EC} \\
(\mathrm{uS} / \mathrm{cm})\end{array}$ & Salinity & TDS & DO & BOD & COD & Hard & Nitrate & Chloride & Copper & Zinc \\
\hline GW1 & 6.2 & 29.85 & 18.3 & 0.009 & 3.59 & 6.34 & 7.8 & 18.6 & 85.9 & 0.003 & 50.03 & 0.002 & 0.56 \\
\hline GW2 & 6.7 & 29.4 & 19.2 & 0.002 & 7.28 & 4.53 & 5.7 & 8.6 & 108.9 & 0.14 & 102.4 & 0.08 & 0.89 \\
\hline GW3 & 6.8 & 29.6 & 10.4 & 0.06 & 6.06 & 5.02 & 6.7 & 12.5 & 217.4 & 0.88 & 75.6 & 0.16 & 1.89 \\
\hline GW4 & 6.3 & 28.99 & 13.6 & 0.01 & 13.54 & 5.32 & 6.8 & 10.9 & 96.4 & 0.68 & 60.89 & 0.2 & 0.78 \\
\hline GW5 & 5.7 & 28.31 & 15.8 & 0 & 45.9 & 4.88 & 7.8 & 7.9 & 108.7 & 0.59 & 112.65 & 0.15 & 1.05 \\
\hline GW6 & 6.9 & 27.9 & 20.5 & 0.003 & 155.9 & 4.98 & 5.3 & 6.5 & 120.5 & 0.76 & 77.67 & 0.19 & 0.67 \\
\hline GW7 & 6.4 & 27.6 & 18.7 & 0.003 & 205.8 & 6.01 & 8.2 & 12.4 & 87.4 & 1.06 & 124.23 & 0.06 & 1.88 \\
\hline GW8 & 7 & 28.6 & 10.2 & 0.06 & 88.3 & 5.53 & 6.9 & 7.5 & 99.6 & 0.56 & 73.95 & 0.12 & 1.67 \\
\hline GW9 & 6.4 & 28.6 & 10 & 0 & 75.12 & 5.68 & 6.5 & 8.4 & 55.6 & 0.06 & 213.6 & 0.04 & 1.23 \\
\hline GW10 & 7.1 & 29 & 19.3 & 0.02 & 378.3 & 6.09 & 7.5 & 10 & 77.9 & 0.88 & 220.5 & 0.07 & 0.66 \\
\hline GW11 & 6.8 & 28.8 & 20.1 & 0.004 & 330 & 5.3 & 6 & 7.5 & 70.4 & 0.45 & 121.4 & 0.0012 & 0.34 \\
\hline GW12 & 6.7 & 28.7 & 16.4 & 0.005 & 157.8 & 5.76 & 7.8 & 8.9 & 40.9 & 1.65 & 58.6 & 0.05 & 0.65 \\
\hline GW13 & 6 & 29.1 & 11.1 & 0 & 34.3 & 4.76 & 6.9 & 7.5 & 340.9 & 1.32 & 45.5 & 0.012 & 0.34 \\
\hline GW14 & 7.1 & 28.2 & 18.6 & 0.001 & 15.3 & 4.67 & 5.4 & 6.5 & 127.5 & 1.01 & 87.5 & 0.001 & 1.34 \\
\hline GW15 & 7 & 28.6 & 12.4 & 0.03 & 3.91 & 5.34 & 7 & 7.1 & 57 & 0.06 & 68.65 & 0.0015 & 1.03 \\
\hline $\mathrm{CP}$ & 6.501 & 28.01 & 20 & 0.004 & 500 & 5.98 & 0.0021 & 40 & 450 & 4.2 & 250 & 1.48 & 2.98 \\
\hline Mean & 6.630769 & 28.61538 & 15.16154 & 0.015077 & 116.1715 & 5.333846 & 6.830769 & 8.738462 & 115.4 & 0.766154 & 103.1338 & 0.081208 & 1.040769 \\
\hline SD & 0.423365 & 0.610105 & 3.959762 & 0.020509 & 121.4728 & 0.549395 & 0.912767 & 3.195279 & 75.43228 & 0.484304 & 53.62262 & 0.071445 & 0.511271 \\
\hline
\end{tabular}

Source: Researcher's Fieldwork, 2021 
Eni, D. Imoke et al., International Journal of Emerging Trends in Engineering Research, 9(3), March 2021, 169 - 175

$>$ Comparison of the quality of water samples from polluted area $(<=500 \mathrm{~m})$ with WHO Standard

Tables 2, 3, 4, compares the quality of water samples from polluted area with WHO standard, the pair sample t-test was conducted for hypothesis one to achieve the second objective of the study. Based on the result of the paired samples correlation test, a significant value of $P=0.023$ was achieved, which was less than the accepted level of significance that is, 0.05 . From the result, a t value of 0.841 was achieved at a degree of freedom (df), 13. In addition, a level of significance $(P 0.023<0.05)$ was achieved, hence the researcher rejected the null hypothesis in favour of the alternate hypothesis. There is a significant mean difference in water quality of the sample points in Mgboji, NdokiOyigbo LGA, Rivers State and WHO standard.

Table 2. Paired Samples Correlations

\begin{tabular}{|c|c|c|c|c|}
\hline & & $\mathrm{N}$ & Correlation & Sig. \\
\hline Pair 1 & $\begin{array}{l}\text { Water quality samples from at non-controlled point } \\
\& \\
\text { WHO standard }\end{array}$ & 14 & -.607 & .023 \\
\hline
\end{tabular}

Source: Researcher's field work, 2021

Table 3 Paired Samples Test

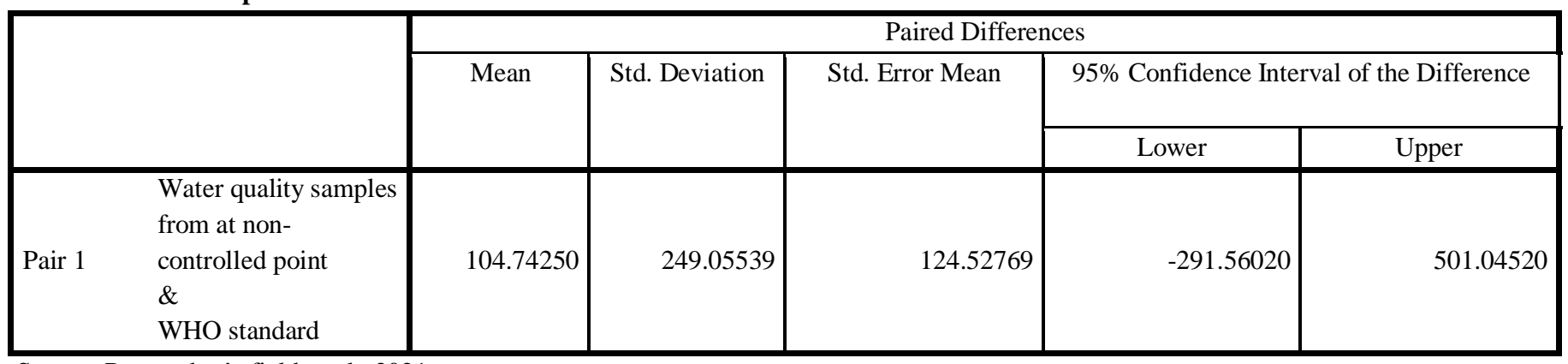

Source: Researcher's field work, 2021

Table 4 Paired Samples Test

\begin{tabular}{|c|c|c|c|}
\hline & $\mathrm{t}$ & $\mathrm{df}$ & $\begin{array}{c}\text { Sig. } \\
(2 \text {-tailed })\end{array}$ \\
\hline $\begin{array}{l}\text { Water quality samples from } \\
\text { Pair 1 non-controlled point } \\
\&\end{array}$ & .841 & 13 & .023 \\
WHO standard & & & \\
\hline
\end{tabular}

Source: Researcher's field work, 2021

$>$ Comparison of the quality of water samples from controlled point $(>=1000 \mathrm{~m})$ with $\mathrm{WHO}$ standard

Also, to compare the quality of water samples from controlled point with WHO standard, paired sample t-test was conducted for hypothesis two to achieve the second objective of the study. Based on the result of the paired samples correlation test, a significant value of $P=0.07$ was achieved, which was more than the accepted level of significance of 0.05 . From the result, a $t$ value of 0.75 was achieved at a degree of freedom (df), 13. In addition, a level of significance (P0.07>0.05) was achieved, hence the researcher accepted the null hypothesis against the alternate hypothesis. That is there is no significant mean difference in water quality from the controlled point in Mgboji, NdokiOyigbo LGA, Rivers State and WHO standard.

Table 5. Paired Samples Correlations

\begin{tabular}{|l|r|r|c|}
\hline & N & Correlation & $\begin{array}{c}\text { Sig } \\
.\end{array}$ \\
\hline $\begin{array}{l}\text { Water quality samples from } \\
\text { Pair 1 } \begin{array}{l}\text { controlled point } \\
\&\end{array}\end{array}$ & 14 & .872 & .07 \\
WHO standard & & & \\
\hline
\end{tabular}


Eni, D. Imoke et al., International Journal of Emerging Trends in Engineering Research, 9(3), March 2021, 169 - 175

Table 6 Paired Samples Test

\begin{tabular}{|c|c|c|c|c|c|c|}
\hline & & \multicolumn{5}{|c|}{ Paired Differences } \\
\hline & & \multirow[t]{2}{*}{ Mean } & \multirow[t]{2}{*}{ Std. Deviation } & \multirow{2}{*}{$\begin{array}{l}\text { Std. Error } \\
\text { Mean }\end{array}$} & \multicolumn{2}{|c|}{$95 \%$ Confidence Interval of the Difference } \\
\hline & & & & & Lower & Upper \\
\hline Pair 1 & $\begin{array}{l}\text { Water quality samples from } \\
\text { controlled point } \\
\& \\
\text { WHO standard }\end{array}$ & 134.23 & 321.02 & 154.9 & -231.44 & 531.04520 \\
\hline
\end{tabular}

Source: Researcher's field work, 2021

Table 7 Paired Samples Test

\begin{tabular}{|l|r|r|r|}
\hline & $\mathrm{t}$ & Df & $\begin{array}{c}\text { Sig. } \\
(2 \text {-tailed })\end{array}$ \\
\hline $\begin{array}{l}\text { Water quality samples from } \\
\text { Pair 1 } \begin{array}{l}\text { at non-controlled point } \\
\& \\
\text { WHO standard }\end{array}\end{array}$ & .90 & 13 & .07 \\
\hline
\end{tabular}

Source: Researcher's field work, 2021

\section{DISCUSSION OF FINDINGS}

The findings of the study availed the comparison of water quality from boreholes collected at from different points that are $500 \mathrm{~m}$ or less from the landfill sites with WHO standard. The result of the paired sample t-test showed that there is a significant mean difference in water quality at the polluted area and WHO standard, with the water quality at the polluted area being higher and lower than the WHO standard. This finding was similar to the findings of Ochekpe (2011) who noted that groundwater located within landfill sites get contaminated within leachates and becomes unpotable for consumption. On the other hand, the paired sample $t$ test between control point and WHO standard showed that there is no significant mean difference between water quality at the controlled point and WHO standard. Similarly, this finding corroborates the findings of Ochekpe (2011).

\section{CONCLUSION}

The study thus concludes that landfill sites pose serious impact on the quality of ground water as a result of leachates that are emitted in to the water table. The emission of the leachates from the landfill sites causes alteration of water quality parameters, thereby making water unsafe for human consumption. Furthermore, the study thus concludes that the farther way borehole sources from the landfill site are usually not contaminated by the pollution from the landfill sites.

\section{REFERENCES}

1. Abur, B. T., Oguche, E. E., \&Duvuna, G. A. (2014). Characterization of Municipal Solid Waste in the Federal Capital Abuja, Nigeria. Global Journal of Science Frontier Research: Environment \& Earth Science, 14(2): 1 -6

2. Akor AJ, Ayotamuno MJ, Aman LI, Enokela SO. Assessment of domestic solid waste generation in PortHarcourt by separator - Receptacle technology. Int. J. Sci. Eng. Res. 2013;4:1-7.

3. Anestina, A.I., Adetola, A \&Odafe, I.B. (2014). Performance Assessment of Solid Waste Management following Private Partnership Operations in Lagos State, Nigeria. Journal of Waste Management Volume 2014; PP 1-9

4. Ekeke, R.O. (2015). The ground water quality of Oyigbo oil center area. (a case study of Afam-Nta community, Oyigbo Local Government Area. Rivers state). An unpublished Bachelor's Thesis from the University of Port Harcourt

5. Ezechi, E.H., Nwabuko, C.G., Enyinnaya\& Babington, C.J. (2017). Municipal solid waste management in Aba, Nigeria: challenges and prospects. Environ. Eng. Res. Vol 22(3); Pp:231-236

6. Elumalai V., Brindha K. \& Lakshmanan E. (2017). Human Exposure Risk Assessment Due to Heavy Metals in Groundwater by Pollution Index and Multivariate Statistical Methods: A Case Study from South Africa. Journal of Water Science. Vol 9; Pp: 234-241

7. Hossain, M.D.L. (2014). Impact of Landfill Leachate on Surface and Ground Water Quality. Journal of Environmental Science and Technology, 7 (6): PP 337-346

8. Nagarajan, R., Thirumalaisamy, S., \&Lakshumanan, E. (2012), Impact of leachate on groundwater pollution due to non-engineered municipal solid waste landfill sites of erode 
Eni, D. Imoke et al., International Journal of Emerging Trends in Engineering Research, 9(3), March 2021, 169 - 175

city, Tamil Nadu, India. Iranian Journal of Environmental Health Sciences \& Engineering. Vol 9(35); Pp: 1-12.

9. Schwarz-Herion, O., Omran, A., \&Rapp, H. P. (2008). A Case Study on Successful Municipal Solid Waste Management in Industrialized Countries by the example of Karlsruhe City, Germany. Journal of Eng. Annals, 6(3): 266 $-273$.

10. Shegow, I.A., \&Funwie, A.D. (2020). Impacts of solid waste management practices on environment and public health: a case study of Wadajir District in Benadir Region of Somalia. International Journal of Current Microbiology and Applied Sciences. Vol 9(7); Pp: 2005-2014 